\title{
Primary Multiple Cerebral Hydatid Disease: Still Symptomatic Despite Pathologically Confirmed Death of the Cyst
}

\author{
Primer Multipl Serebral Kist Hidatik: Patolojik Olarak Gösterilen Kist \\ Ölümüne Rağmen Semptomatik Bir Olgu Sunumu
}

Umut YAKA, Yavuz ARAS, Aydın AYDOSELI, Mehmet Osman AKCAKAYA, Altay SENCER, Murat IMER, Kemal HEPGUL

Istanbul University, Istanbul Faculty of Medicine, Department of Neurosurgery, Istanbul, Turkey

Corresponding Author: Mehmet Osman AKCAKAYA / E-mail: moakcakaya@gmail.com

\begin{abstract}
Hydatid disease is a life-threatening parasitic infestation caused by Echinococcus granulosus. Infection with E. granulosus typically results in the formation of hydatid cysts in liver, lungs, kidney and spleen. Majority of the intracranial cysts are secondary and solitary. Multiple primary cerebral cysts are uncommon. Surgical and medical management of a 14-year-old boy with multiple primary hydatid cysts are presented. 14 cysts, which were symptomatic due to their mass effect, were surgically removed, whereas a deep-seated asymptomatic cyst was followed-up with medical treatment. Despite proper antibiotic regimen the patient was admitted with epileptic seizures six months later. The deep-seated lesion was also surgically removed. Intraoperative observations and pathological examination demonstrated different characteristics, with pericystic gliosis, gel-like cyst content and death scolices within the cavity. In addition to the fact, that the presented case is an additional example for the rare primary multiple cerebral hydatid cysts, to our knowledge it is the first case of a dead cerebral hydatid cyst, causing symptoms despite effective medical treatment.
\end{abstract}

KEYWORDS: Hydatid cyst, Epilepsy, Cerebral, Multiple, Primary, Dead scolex

Öz

Hidatik kist hastalığı, Echinococcus granulosus'un neden olduğu hayatı tehdit eden parazitik bir enfestasyondur. E. granulosus tipik olarak karaciğer, akciğer, böbrek ve dalakta kist oluşumu ile sonuçlanır. İntrakranyal kistlerin büyük çoğunluğu soliter ve sekonderdir. Multipl primer serebral kist hidatik oldukça nadir görülür. Bu yazıda, 14 yaşında erkek hastada her iki hemisferi de tutan ve farklı özellikler gösteren bir primer multipl serebral kist hidatik olgusu sunulmaktadır. Kitle etkisine bağlı olarak semptomlara neden olan 14 kist cerrahi olarak çıkartılırken, derin yerleşimli ve asemptomatik olan kist medikal tedavi ile takip edilmiştir. Uygun antibiyotik tedavisine rağmen hasta altı ay sonra epileptik nöbet ile başvurmuş ve derin yerleşimli lezyon da ameliyat edilmiştir. Cerrahi sırasındaki gözlemler ve patolojik inceleme farklı özellikler göstermiştir: Perikistik gliozis, jel kıvamında kist içeriği ve kist kavitesi içinde ölmüş skoleksler. Sunulan olgu; nadir görülen primer multipl serebral kist hidatik olgularından biri olması dışında, bildiğimiz kadarıyla etkin medikal tedavi ile ölmüş kist hidatik lezyonlarının da semptomlara neden olabileceğini gösteren tek olgu olması bakımından önemlidir.

ANAHTAR SÖZCÜKLER: Kist hidatik, Epilepsi, Serebral, Multipl, Primer, Ölü skoleks

\section{INTRODUCTION}

Hydatid cyst disease is seen worldwide, but particularly in livestock producing countries (2). Although it is known that there are twelve different species of Echinococcus, mainly two types including Echinococcus granulosus and Echinococcus multilocularis cause disease in humans (8). Echinococcus granulosus is endemic in some regions of the world including Central Europe, Mediterranean countries, the Middle East, South America, Australia, New Zealand and South Africa $(2,5,8,10,12,17,24,31)$. The incidence of the disease in endemic regions ranges from 0.00003 to 0.0005 (8). Lung and liver involvement are commonly seen after parasitic infestation, but cerebral involvement is approximately $1-3 \%$ of patients infected with the parasite, and this portion represents only $2 \%$ of all intracranial space-occupying lesions $(6,12,13)$. 50-70\% of cerebral cystic echinococcosis is encountered in children and young adults $(9,17,23,24)$. However, cerebral hydatid cysts are generally seen as single lesions $(20,28)$ and multiple cerebral cystic echinococcosis is a seldom entity in the setting of hydatid cyst disease $(3,4,6,7,11,13,15,16,18,19,21,22,25$ 29,33).

\section{CASE REPORT}

A 14-year-old boy, the member of a family dealing with stockbreeding was admitted to the hospital with the complaints of double-vision, unremitting headache, nausea 
and vomiting. Neurological examination revealed bilateral papilledema and paralysis of left abducens nerve. Cranial MRI showed two lesions; one was a multicystic lesion in the left occipital lobe $8 \times 5.5 \times 4 \mathrm{~cm}$ in size. This lesion was isointense to CSF on all sequences and compressed the left trigone and posterior horn of the left lateral ventricle (Figure 1). The second lesion was located in the insula posteriorly measuring $3 \times 3 \times 2 \mathrm{~cm}$ in size (Figure 2). The patient was scanned to

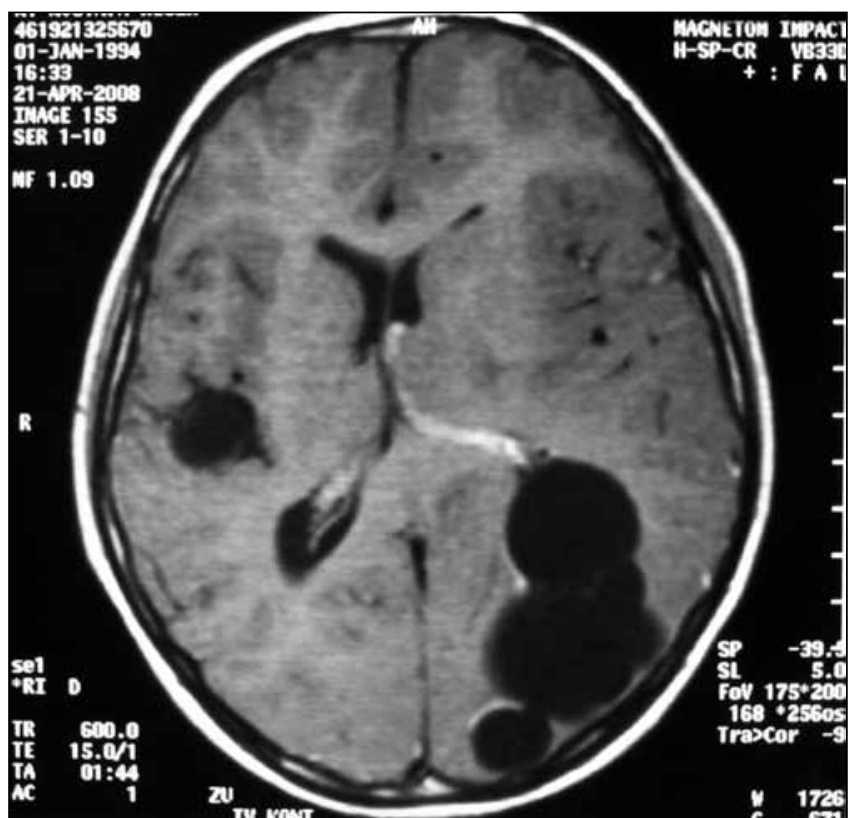

Figure 1: T1-weighted axial MRI demonstrates non-enhancing left occipital multiloculated cystic lesion and an accompanying right temporal cyst. evaluate other possible organ involvements. Chest X-rays, abdominal ultrasonography and cardiac echo detected no findings suggestive of other systemic involvement of hydatid cyst disease. Additionally, serological tests including Casoni, Weinberg and indirect hemagglutination tests were unremarkable. Routine laboratory tests were within normal limits.

The cystic lesion in the left occipital lobe was removed surgically to relieve the significant cyst-related mass effect. This multicystic lesion consisting of 14 cysts was removed totally without rupture. A relatively large craniotomy was applied and cortical dissection was performed. Care was taken to avoid the rupture of the cysts during cortical dissection. A soft rubber catheter was inserted between the cortex and the cysts. Using Dowling's water hydrodissection technique (5), namely contiunous warm saline injection through the catheter, 14 cysts were delivered one-by-one without rupture. Histopathological examination confirmed hydatid disease caused by Echinococcus granulosus. The cystic lesion in the other hemisphere, however, was smaller in size, deep-seated and caused no significant mass effect. Surgical removal of this cyst was postponed, and albendazole treatment was administered (15 mg/kg/day) with close monitoring instead. The patient was neurologically intact on discharge. Six months after surgery, he was admitted to the hospital for two consecutive seizures (one resulting in status epilepticus), although he was under anti-epileptic therapy. His neurological examination was normal. Control MRI demonstrated that the former cystic mass in the right temporal lobe was transformed into a contrast-enhancing thick-walled lesion with severe peripheral edema (Figure 2). Upon these radiological and clinical findings, a right temporal craniotomy was performed

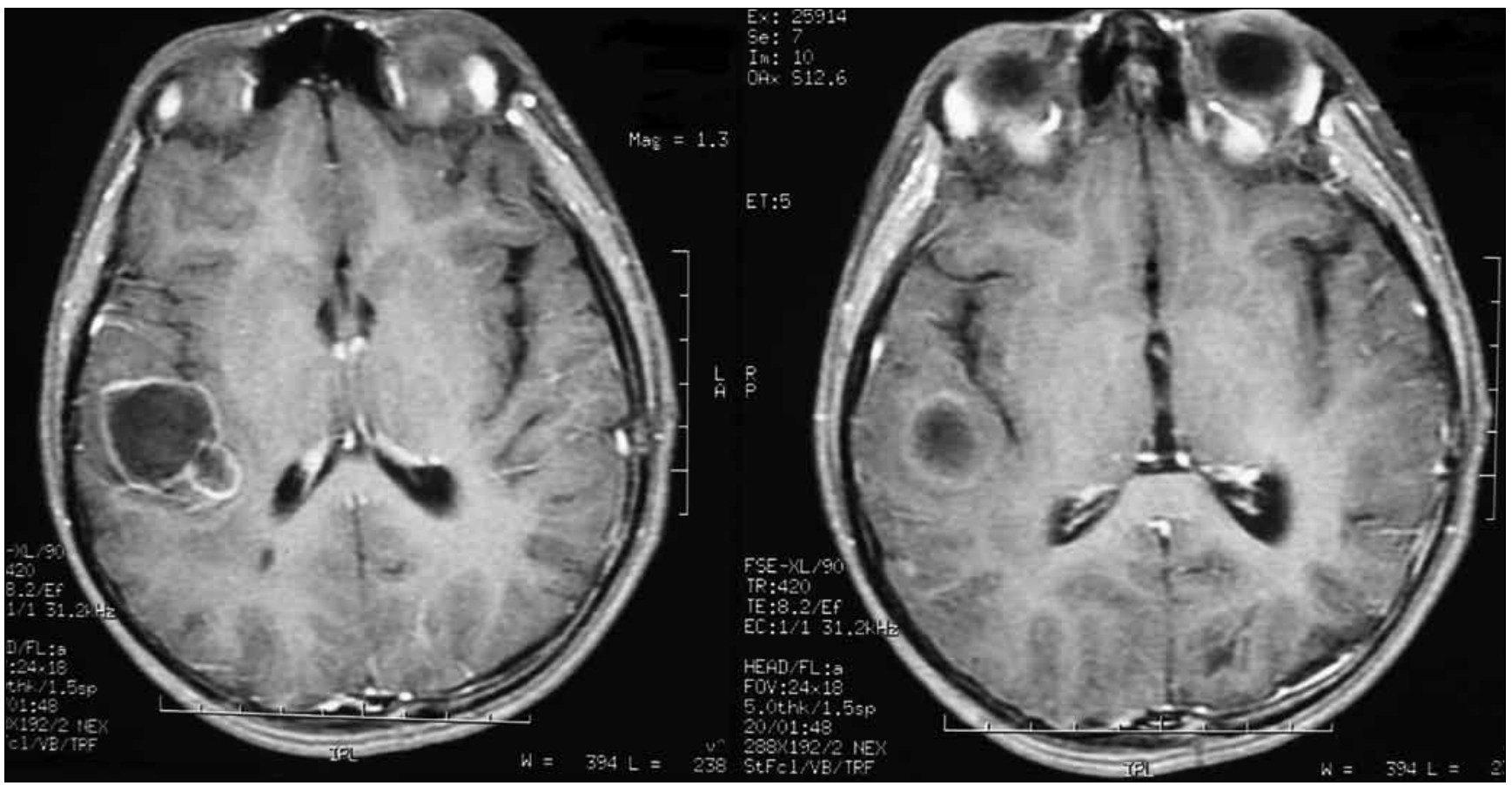

Figure 2: T1-weighted axial MRI demonstrates enlargement and new peripheral contrast enhancement. 
to remove the cyst. The capsule was punctured, but no liquid or viscous material leaked out. Therefore, a small incision was performed on the cyst wall and the gel-like cyst content was excised "en bloc" with its capsule. Histopathological examination demonstrated lamellar membranes and dead scolices in the cyst contents. Postoperative MRI revealed that cystic lesions in both hemispheres were totally removed (Figure 3). Albendazole treatment was continued for two extra months after the second surgery. In the two-year follow-up period, no epileptic seizures, neurological deficits or sequel observed and follow-up radiological exams showed no evidence of hydatid disease.

\section{DISCUSSION}

The central nervous system is involved in $1-3 \%$ of patients with hydatid disease. $(5,8,10,12,17)$ Clinical findings include headache, cranial nerve involvement, papilledema, focal neurological findings, cognitive impairment, convulsions and rarely hemichorea $(7,13,17,24)$. Magnetic resonance and computerized tomography scans characteristically show hydatid cysts as spherical, well-defined, non-enhancing cystic lesions without peripheral edema. The cysts in MRI are seen as non-contrast enhancing, isointense lesions in both T1and T2-weighted images $(8,9,10,14,30)$. Neither perilesional edema nor rim fashion contrast enhacement are common radiological findings of hydatid cysts. (14) Cerebral hydatid cysts are usually located supratentorially in the middle cerebral artery territory, and rarely located in the posterior cranial fossa or ventricles $(16,20)$.

Surgery is the treatment of choice for symptomatic and large cerebral hydatid cysts. The aim of the surgery is the intact delivery of these cysts $(14,31)$. Dowling's hydrodissection technique (5) is the most useful method for intact delivery. For multiple cysts; as in our case, an extra care should be taken to avoid the rupture during the extirpation of the cysts. Our suggestion is to deliver multiple cysts one-by-one patiently. In case of a rupture, careful suction must be performed in order to remove cyst content and surgical field must be irrigated with hypertonic saline solution $(14,31)$. When a rupture occurs, it usually results in serious complications besides the risk of contamination. Anaphylactic reaction, chemical meningitis, permanent neurological deficits or even death may occur (14).

Primary hydatid cysts can transform into huge masses. These cystic masses grow slowly, so the brain accommodates itself to this growing mass. In this growing process, cysts become older and collapse due to the degenerations in the germinal layer (32). In other words "autosterilization" occurs. The content of the cyst becomes more dense, looses its clarity ("rock water clarity") and becomes "cholesterol-rich". Inflammatory changes occur due to the leakage of this content and a granulation tissue develops around the cyst, leading to the death and calcification of scolices within the cystic cavity (32). With the administration of proper medical treatment in the present case, this process might have been accelerated. To our knowledge, this is the first case of a dead cerebral hydatid cyst, causing symptoms despite effective

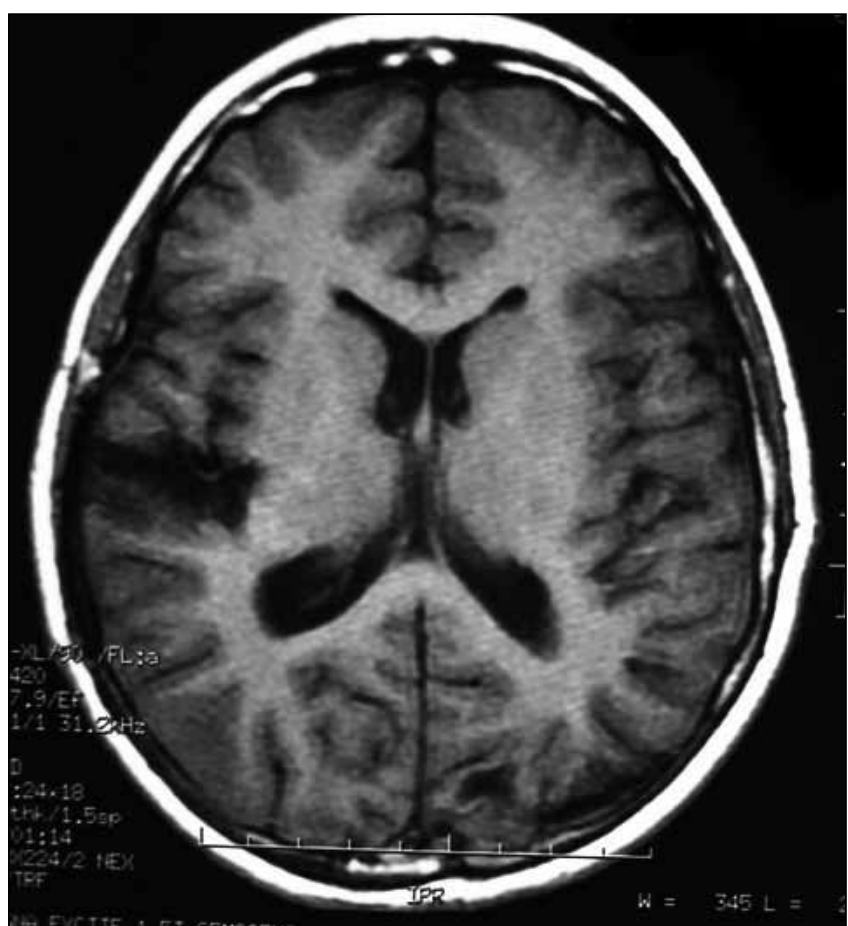

Figure 3: Control MRI confirms complete surgical removal of both lesions.

medical treatment. Pathological examination confirmed the effectiveness of albendazole treatment with the presence of death scolices within the cyst cavity, however morphological changes such as pericystic gliosis and peripheral edema were probably responsible for the epileptic seizures.

Cerebral hydatid cysts are almost always seen as single lesions $(20,28)$. Multiple cerebral hydatid cysts are extremely rare $(3,4,6,7,11,13,15,16,18,19,21,22,25-29,33)$. To our knowledge, there are only 18 case reports of primary multiple hydatid cysts. Regardless of the localization of the lesion and the treatment modalities (surgical or medical), clinical outcome of the reported patients are generally good. However, it is obviously unreliable to draw a certain conclusion regarding the optimum treatment strategy and the prognostic factors in the issue of multiple intracranial hydatid cysts in pediatric population based on the limited data derived from these previously reported cases. It is generally agreed that the treatment of the symptomatic hydatid cysts with the signs and symptoms of increased intracranial pressure is surgical removal. Nevertheless, medical treatment may be preferred in asymptomatic and deep-seated lesions $(1,19,21,29)$. Three of the reported 18 cases in the literature were managed with medical treatment only, whereas two cases were managed with surgery and medical treatment. In our case the symptomatic lesion was surgically treated and asymptomatic lesion was followed up with albendazole treatment. However, asymptomatic cyst became symptomatic with two consecutive epileptic seizures, six months after the institution of proper antibiotic regimen. Therefore, we now tend to prefer surgical removal as the first treatment of choice for both 
symptomatic and asymptomatic intracranial hydatid lesions. The rationale behind this approach can be explained by the fact that asymptomatic cysts treated with medical treatment can die but they can still be symptomatic. The surgical approach for the removal of these death cysts is technically more challenging than straightforward hydrodissection surgery alone.

However, we still need more data regarding multiple intracranial hydatid lesions, as in our case. Collaboration of the health centers from the endemic areas is needed in order to determine the optimum treatment strategy including the timing and the order of surgical removal of the cysts as well as the use antibiotic treatment.

\section{REFERENCES}

1. Al Zain TJ, Al-Witry SH, Khalili HM, Aboud SH, Al Zain FT Jr: Multiple intracranial hydatidosis. Acta Neurochirurgica (Wien) 144: 1179-1185, 2002

2. Andronikou S, Welman CJ, Kader E: Classic and unusual appearances of hydatid disease in children. Pediatr Radiol 32: 817-828, 2003

3. Baysefer A, Erdogan E, Gonul E, Kayali H, Timurkaynak E, Seber $\mathrm{N}$ : Primary multiple cerebral hydatid cysts: Case report with CT and MRI study. Minim Invasive Neurosurg 41: 35-37,1998

4. Bilge T, Batur S, Bilge S, Aydin Y, Aksoy B, Senol S: Primary multiple hydatid cysts of the brain: Case report. Surg Neurol 39:377-379, 1993

5. Carrea R, Dowling E Jr, Guevara A: Surgical treatment of hydatid cysts of the central nervous system in the pediatric age (Dowling's technique). Child's Brain 1: 4-21, 1975

6. Cataltepe O, Tahta K, Colak A, Erbengi A: Primary multiple cerebral hydatid cysts. Neurosurg Rew 14: 231-234, 1991

7. Cavusoglu H, Tuncer C, Ozdilmac A, Aydin Y: Multiple intracranial cysts in a boy. Turk Neurosurg 19(2): 203-207, 2009

8. Ciurea AV, Fountas KN, Coman TC, Machinis TG, Kapsalaki EZ, Fezoulidis NI, Robinson JS: Long-term surgical outcome in patients with intracranial hydatid cyst Acta Neurochir 148: 421-426, 2006

9. Duishanbai S, Jiafu D, Guo H, Liu C, Liu B, Aishalong M, Mijiti $\mathrm{M}$, Wen H: Intracranial hydatid cyst in children: Report of 30 cases. Childs Nerv Sys 26: 821-827, 2010

10. El-Shamam O, Amer T, El-Atta MA: Magnetic resonance imaging of simple and infected hydatid of the brain. Magn Reson Imaging 19: 965-974, 2001

11. Erkutlu I, Buyukhatipoglu H, Alptekin M, Gok A: Where is the brain parenchyme? "Primary cerebral multiple cyst hydatid". Intern Med 47: 333, 2008

12. Ersahin $Y$, Mutluer $S$, Guzelbag E: Intracranial hydatid cyst in children. Neurosurgery, 33: 219-225, 1993

13. Iplikcioglu AC, Ozek MM, Ozer AF, Ozgen T: Periventricular hydatid cyst presenting with hemichorea. Child's Nerv Syst 9: 292-293, 1992

14. Izci Y, Tuzun Y, Secer HI, Gonul E: Cerebral hydatid cysts: Technique and pitfalls of surgical management. Neurosurg Focus 24(6): E15, 2008
15. Gupta SK, Tandon SC, Khanna S, Asthana S: Case report: Multiple intracranial hydatid cysts with post-operative dissemination. Clin Radiol 44: 203-204, 1991

16. Karadag O, Gurelik M, Ozum U, Goksel HM: Primary multiple cerebral hydatid cysts with unusual features. Acta Neurochir (Wien) 146: 73-77, 2004

17. Kaya U, Ozden B, Turker K, Tarcan B: Intracranial hydatid cysts. Study of 17 cases. J Neurosurg 42: 580-584, 1975

18. Mancuso $P$, Noubari BA, Gurusinghe NT: Multiple primary cerebral hydatid cysts: Case report. $\mathrm{Br} J$ Neurosurg 11: 248-249, 1997

19. Martin Oterino JA, Chimpen Ruiz VA, Reviriego Jaen G, Sanchez Rodriguez A: Repeated strokes as a sign of multiple cerebral hydatid cysts. Neurologia 11: 307-309, 1996

20. Muthusubramanian V, Pande A, Vasudevan MC, Ravi R: Surgical management of brainstem hydatid cyst- an unusual site. Surg Neurol 71: 103-106, 2009

21. Nowak DA, Lucking MO, Böhmer RH, Schrenier R, Fuchs $H H$, Flügel KA: Isolated intracerebral cystic echinococcosis: Unusual presentation of a rare disease. Dtsch Med Wochenschr 127: 1638-1642, 2002 (Article in German)

22. Nurchi G, Floris F, Montaldo C, Mastio F, Peltz T, Coraddu M: Multiple cerebral hydatid disease: Case report with magnetic resonance imaging study. Neurosurgery 30: 436-438, 1992

23. Onal C, Barlas O, Orakdogen M, Hepgul K, Izgi N, Unal F:Three unusual cases of intracranial hydatid cyst in the pediatric age group. Pediatr Neurosurg 26: 208-213, 1997

24. Onal C, Unal F, Barlas O, Izgi N, Hepgul K, Turantan Ml, Canbolat A, Turker K, Bayindir C, Gokay HK, Kaya U: Long-term follow-up and results of thirty pediatric intracranial hydatid cysts: Half a century of experience in the Department of Neurosurgery of the School of Medicine at the University of Istanbul (1952-2001). Pediatr Neurosurg 35(2): 72-81, 2001

25. Ozkan U, Kemaloglu MS, Selcuki M: Gigantic intracranial mass of hydatid cyst. Child Nerv Syst 17: 623-625, 2001

26. Pasaoglu A, Orhon C, Akdemir H: Multiple primary hydatid cysts of the brain. Turk J Pediatr 31: 57-61, 1989

27. Popli MB, Khudale B: Primary multiple hydatid cysts of the brain. Australas Radiol 42: 90-91, 1998

28. Sharma A, Abraham J: Multiple giant hydatid cysts of the brain. Case report. J Neurosurg 57: 413-415, 1982

29. Todorov T, Vutova K, Petkov D, Balkanski G: Albendazole treatment of multiple cerebral hydatid cysts. A case report. Trans R Soc Trop Med Hyg 82: 150-152, 1988.

30. Turgut AT, Turgut M: Magnetic resonance imaging of hydatid cysts of the brain. Magn Reson Imaging 22(9): 1339-1340, 2004

31. Tuzun Y, Kadioglu HH, Izci Y, Suma S, Keles M, Aydin IH: The clinical, radiological and surgical aspects of cerebral hydatid cysts in children. Pediatr Neurosurg 40(4): 155-160, 2004

32. Yolas C, Gundogdu C, Yakut C: Dead cerebral cyst hydatid ( A case report). Turk Norosirurji Dergisi 3: 38-40, 1993 (Article in Turkish)

33. Yurt A, Avci M, Selcuki M, Ozer F, Camlar M, Ucar K, Tasli F, Altınors N: Multiple cerebral hydatid cysts. Report of a case with 24 pieces. Clin Neurol Neurosurg 109: 821-826, 2007 